Caderno de Poesia V

Avani Souza Silva ${ }^{1}$

\title{
Saudades de Havana
}

Meu coração salsa, mamba, rumba, bolera, guajira

Lamenta, batuca, canta,

Dança som, som e dança

Faz trovas...

Havana me emociona e aprisiona.

Vagam pelo Malecón violentas vagas,

Lá meu espírito vagabundeia discreto.

No Boulevard do Prado meus pés se arrastam indolentes,

Meus olhos procuram um banco na Praça José Martí

Quero ouvir a cidade e o pulsar calmo de sua vida mundana.

Minha sede se aquieta com os copos de refrescos,

Minha boca se delicia de sorvete.

Pan con cerdo mata minha fome transeunte,

Bananas fritas me dão saudades retirantes de minha terra.

Trago Havana inteira na alma, quase toda em meu nome

As cores gastas de Habana Vieja restauradas em mim:

Vibram rosas, amarelas, azuis, verdes intensos.

Suas ruas estreitas, ensolaradas ou escuras,

Meus largos e iluminados caminhos.

Seus prédios velhos, carcomidos, ruínas,

Molduras de coragem nas janelas.

Uma brisa tépida acaricia Palmeiras Reais,

Lembra o vento fustigando as bananeiras de casa.

Suas folhas, as crinas de meus cavalos a galope.

Guero voltar para Havana,

Lá eu me sinto em casa.

Lá não vejo crianças abandonadas,

${ }^{1}$ Mestre em Estudos Comparados de Literaturas de Língua Portuguesa. FFLCH-USP. 
Cães sem dono, velhos de rua,

Maratona de desempregados vendendo balas nos faróis,

Nem propagandas, nem luzes fortes, coloridas, violentas,

Piscando loucas intermitentes,

Querendo que eu compre isso e aquilo, e mais aquilo e isso.

Reconheço no povo cubano meus irmãos do Glicério,

do Terminal Bresser, do Parque D. Pedro,

Da 25 de Março, do Mercado da Cantareira,

Circulando habaneros...

Somos todos iguais.

Vejo uma juventude perturbadoramente bonita, vibrante

$\mathrm{E}$ mulheres alegres, com roupas coloridas, de flores.

Laicas, lycras e lycras...

E negros risonhos, lustrosos,

E velhinhos de chapéus, lendo jornais.

E crianças indo para a escola, em grupos pelas calçadas,

a professora à frente.

E carros antigos, saídos dos filmes.

Adoro comer arroz congris,

Arroz moro.

O abacate amacia a salada e salga minha boca,

Apaga o gosto de vitamina com leite.

Que saudades eu tenho de Havana...

Virgen de la Caridad del Cobre!

Obaluaiê!

\section{Notas:}

Arroz congris: arroz cozido com feijão preto.

Arroz moro: arroz cozido com feijão vermelho.

Habanero: povo de Havana.

Habana Vieja: centro histórico de Cuba, patrimônio histórico mundial tombado pela UNESCO.

Virgen de la Caridad del Cobre: Padroeira de Cuba, santa morena encontrada no mar por indígenas, próximo a Santiago de Cuba. No sincretismo afro-cubano é a Oxum. Equivale no Brasil a Nossa Senhora Aparecida, santa negra, cuja imagem foi encontrada por pescadores no Rio Paraíba do Sul.

Obaluaiê: São Lázaro, santo protetor no sincretismo afro-cubano. 